\title{
«Rural-urban divide or continuum?» \\ On the consequences of female labour migration to Bangkok for rural-urban interactions in an age of globalisation
}

\section{Anne Clausen, Cologne}

\section{Socio-spatial transformations in the context of migration and globalisation}

People have always migrated. Recent globalisation dynamics, however, significantly alter the conditions and features of migration. This paper analyses ruralurban interactions as shaped by female labour migrants in a globalising Thailand. The central question is how female migrants in Bangkok constitute space through their relationships with their rural origin and concisely, whether female labour migration is situated within a Bangkok - periphery divide or continuum. The Thai case is particularly interesting because Thai societal norms, based on Theravada Buddhism, are often claimed to support female migration better than other cultures (OSAKI 1999; CURRAN 1998). Specifically, only the migration streams from the rural towards Bangkok and its vicinity and the migrants who are employed in the industrial sector are targeted. In analysis one has to consider that the globalisation process is commonly applied to almost every contested contemporary issue and is sometimes (arguably) merged with other, overlapping debates.

Globalisation stands, generally speaking, for ever increasing worldwide networking that takes place simultaneously at various levels and dimensions. In its consequence, however, it equally pushes rapid, unpredictable socio-economic changes, disembeddedness and disjunctures, because individual lives, cultures and identities are caught in-between different places, networks, the global and the local (BECK 1999; MASSEY 1994; Appadurai 1996). Likewise Thai female migrant workers have to meet (1) their roles as industrial workers in Bangkok, (2) an environment of urban modernity, and (3) their rural cultural-economic traditions. As a result, each migrant produces a distinct pattern of Bangkok-periphery interactions which represent expressions of contemporary social-spatial transformations in Thailand.

The compression of time and space inherent in globalisation - deterritorialisation - transforms places from bound items to sets of networks in motion. Migration is then understood as a system of complex interrelationships and interdependencies between two localities. It becomes the most visible form of rural- urban interactions (TACOLI 1998). Territoriality is gradually substituted by translocality and globalisation occurs locally and globally embedded as glocalisation (ROBERTSON 1998). The wider socio-economic, politi$\mathrm{cal}$, and spatial contexts become interconnected with the practical experiences of migrants and their families (WerLen 2000). Micro and macro-scales of ruralurban interactions, which naturally serve as indicators of interdependence between (people in) geographical areas, become closely attached (UlLman 1980). Altogether, an integrative approach is claimed to best interlink migration with rural-urban interactions and globalisation and is thus applied in this study as schematised in Fig. 1 (Robinson 1996; Kelly \& Olds 1999).

Female labour migrants encounter globalisation specifically while searching for industrial employment in urban agglomerations like Bangkok. The feminisation of (industrial) employment and the feminisation of labour migration in fact demonstrate two sides of the same phenomenon. As an abundant and cheap work force, the women represent a major factor for their country's integration into global markets through industrialisation - which in turn is often regarded as the best catalyst for poor countries to catch up with development (Gosh 1999). As the periphery does not offer any perspectives to them any more, the women increasingly move towards the available jobs in the urban market places of globalisation (SKELDON 1997, 1999). Hence, the female migrant workers are somewhat included in the new world system, but experience has shown that they are at the same time stripped of many legitimate rights (MogHADAM 1999).

Deterritorialisation jeopardises traditional social structures when it generates cross-cultural networks between people in various localities as opposed by traditional relations within only one locality. Specifically migrants have to deal with diverse socio-spatial environments at the same time (Olwig 1997; GupTA \& Ferguson 1997). In the Thai case at hand, literally the traditional daughter meets the modern woman. Hence, while moving between village and city, each migrant must negotiate not only shifts in space and labour but also shifting social relations, personal identities, and life-styles. This process is feared to bring about personal, familial, and societal conflicts because in a response migrants may break or retain rural-urban interactions (APPADURAI 1996; STALKER 2000). 


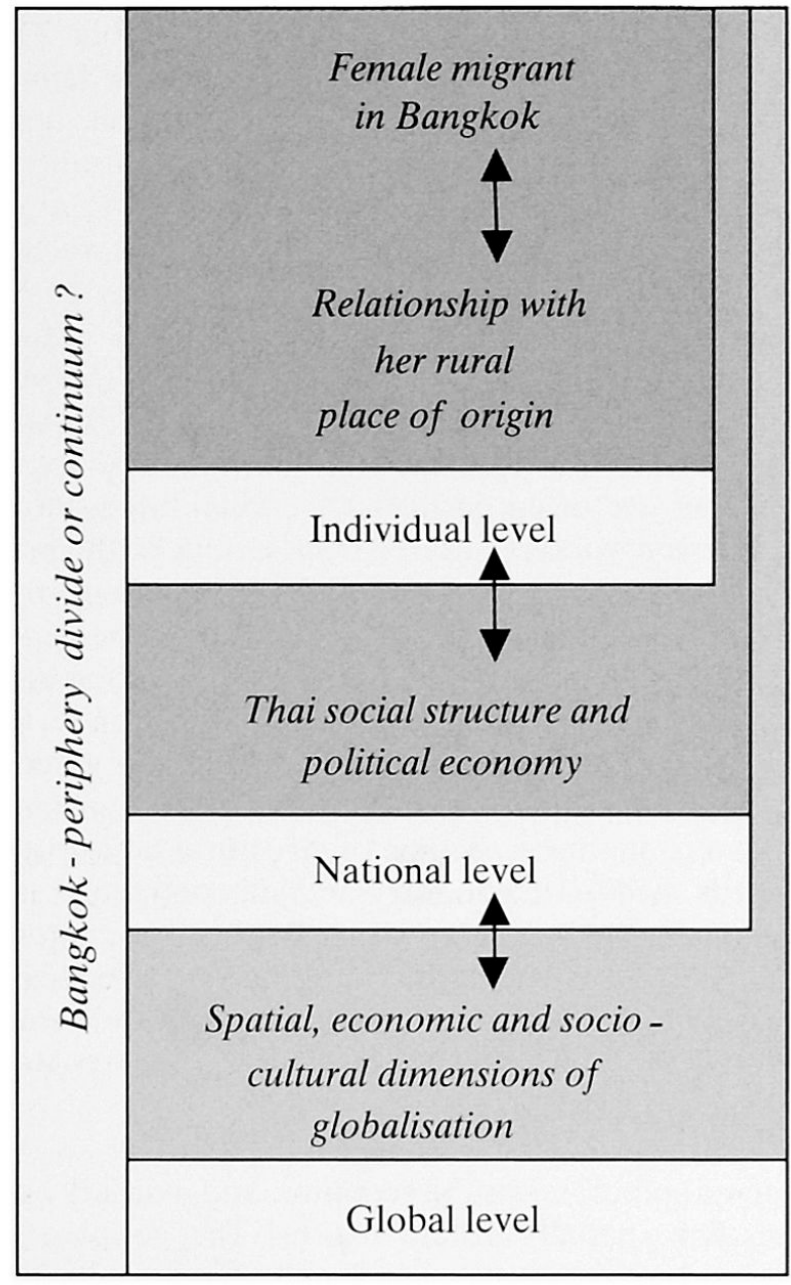

Fig.1: Integrative, multi-perspective approach of the study

Integrative, multidimensionale Perspektiven der Studie

Perspectives intégratives et multidimensionnelles de l'étude

Draft: A. Clausen

Two characteristics pointing at a rural-urban divide or continuum are utilised in this paper. The nature and transformation of migrants' social exchange networks are the first indicator. Social networks are structures which link people by a common social, economic or political interest or obligation, based on direct personal acquaintance. Only social networks of exchange, however, represent integrative bridges which close the gap between overall organisation and individual action, between the local and the global (GranovetTER 1973; CURRAN 1998). As the second indicator, the migrants' localised identity, here their perceptions of belonging and affiliation and where - in the periphery or in Bangkok - these are located, are examined (MASSEY 1994). The household level, i.e. links between inner-personal and inner-familial divides and continu- ums are significant, too. In this context the new economics of migration concept presumes that the decision to migrate is motivated primarily by the household in order to minimise risks and diversify resources (ChAnt 1998; StaRK 1991).

Summed up, the paper's objective is to identify, analyse and explain the migrants' socio-spatial relationships with the rural against the background of national and global socio-economic processes. As outlined, the focus is always on the geography of rural-urban circulation in Thailand, here on the question: Is female labour migration situated within a Bangkok-periphery divide or continuum?

The paper concentrates precisely on certain aspects of the consequences of rural to urban migration in its interwoven, globalised Thai context. This is important to note as most existing migration studies - and Thailand is no exception - deal with matters of induction or perpetuation of migration. Their understanding of migration is usually narrower. Here migration is understood as a socio-spatial more than a strict demographic process. As such it implies and connects economic, political, social, and cultural dynamics. Therefore, the rural-to-urban passage is (at least initially) perceived as a move from a relatively traditional to a modern context (United Nations Secretariat New YORK 1993). Such approach may imply some stereotypes, yet stereotypes help to discern otherwise hardly recognisable processes (RAPPORT 1996).

\section{Methodology}

This article is based on a research study which included a three-month research period in Bangkok from November 2000 until January 2001. A mixed research approach was chosen comprising (1) fourteen problemcentred and focussed expert interviews, (2) visits to six industrial areas and trade union centres where eight female migrant factory workers in three groups were interviewed, plus (3) the analysis of related statistics.

The interview partners comprise gender, labour, and migration-specific experts from Thai universities, UN agencies, and non-governmental organisations. Due to culture and language barriers, contacts with the migrants themselves could only be established through these institutions. This dependency might have caused somewhat biased insights. Therefore, the study is not generally transferable.

In January 2002 the research results were presented to a discussion forum of UN and non-UN professionals, many of whom had given interviews in Bangkok. The experts' feedback is integrated in this article. 
Spatially, the study focuses the Bangkok Metropolis plus the five neighbouring provinces (altogether the Bangkok Metropolitan Region, BMR) against the Southern, Northern, Central and North-Eastern regions of Thailand. If the urban character is only relevant in social-cultural terms Bangkok refers to the BMR.

\section{National perspectives on rural-urban interactions: Shifts in labour, gender roles, and space in Thailand}

Fig. 2 offers a systematic overview on national dimensions of rural-urban interactions in Thailand. They represent the structural arena of female migrants' changing biographies. Labour-intensive export-oriented manufacturing was - and still is - a key factor for Thailand's economic transition from a rice-agricultural to a globalised Newly Industrialising Country (NIC). Between 1986 and 1999 the industrial exports rose from $55.35 \%$ to $84.27 \%$. The gross domestic product (GDP) growth rate in manufacturing averaged at high $9 \%$ between 1987 and 1995. Globalisation and industrialisation processes concentrate in Bangkok and its vicinity: $75 \%$ of foreign direct investment, $50 \%$ of GDP production (1998), 62\% of all manufacturing establishments (1999), and $62 \%$ of industrial labourers (1999) were located there (Ogena et al. 1997; THAILAND DeVElopment Research Institute 2000a; MinisTRY OF Labour and Social Welfare 1999). As a result, macro-economic regional disparities are exacerbated and opportunities are accumulated one-sided. Peoples' movements towards the urban Central Region (i.e. presumably the vicinity) and Bangkok Metropolis are intensified (in August $200024.5 \%$ and 12,7\% respectively of the population were migrants) (NATIONAL STATistical Office 2000). Bangkok Metropolis has now about 10 million inhabitants which total about $16 \%$ of all Thais and $60 \%$ of the urban Thai population. It is 33 times bigger than the country's second largest city and has therefore the highest primacy index worldwide.

Particularly young single women from the Northeastern and Northern Regions meet the demand for cheap, flexible and legally unprotected labour force and dominate the rural-to-Bangkok flows. Accordingly, the sex ratio of interregional migrants in 1997 equalled 173.9 in the Northeast, 126.9 in the North but only 95.3 in Bangkok (National Statistical Office 1997). In 2000 female workers outnumbered male workers in the five leading export industries, totalling between $55 \%$ and $76 \%$ (Gender and Development Research Institute 2000).

As a result, social roles are to an extent being redefined: Traditionally the domestic sphere belongs to Thai women whereas men deal with all external affairs. In contrast, as migrants the women often earn their family's livelihood and represent them in public. They thereby strengthen their personal and their familial (community-wide) autonomy and reputation, hence somewhat experiencing economic and cultural empowerment. However, their presence as workers is largely confined to low-income, unskilled jobs and declines the higher up the skills and wage ladder they go. For instance, female workers comprise only $28 \%$ in highincome jobs, opposed by $72 \%$ male workers (GENDER and Development Research Institute 1999). Additionally, health conditions in labour-intensive export industries are often particularly critical. Many of the interviewed workers suffered from serious health problems because their workload had been disproportionably increased during the last years to keep the factory competitive - and they receive no compensation at all. Moreover, the high concentration of women in sectors submitted to the world market enhances their vulnerability towards rapid structural turnovers. For instance, they were the main victims of structural adjustments towards medium-technology and subcontracting productions in the beginning 1990s. During the economic crisis 1997/98 particularly young and little educated workers in manufacturing, yet not necessarily women, suffered the most (Ogena et al. 1997; World Bank Thailand Office 2000).

In geographical terms the economic and mobility processes link spatially distant regions. The periphery of Thailand is integrated in a (macro-) economically functional system with the mega-city and its vicinity. Bangkok and its surroundings offer employment and participation in the (global) economy while the remaining four regions, especially the Northeast and the North, supply a cheap work force and in turn benefit economically from their migrants (CHAMRATRITHIRONG et al. 1995; PARnwell \& RIGg 1996). The economic crisis $1997 / 98$ highlighted the crucial function of this circulation system through migration as an informal safety net against the volatility of globalisation. When employment in the industrial sector declined at $-17.2 \%$ and the GDP growth rate in manufacturing fell to $-11.4 \%$ (compared to $-3.1 \%$ in agriculture and $-0.4 \%$ in services), many migrant workers returned home. Although normal seasonal flows were not exceeded, the rural economies could not absorb them and forced them to move back to Bangkok empty handed. Since then the Thai government has recognised that active ruralurban interactions, if actively maintained, can create a dynamic economy and society, improve the living standards of the people in both areas, and protect them in times of need. Accordingly, on the microlevel, stable family and community relations are now regarded as the prerequisite for political, economic and environmental development (SKELDON 1997; GRAY 1999; World Bank Thailand Office 2000; Thailand Development Research Institute 2000b). 

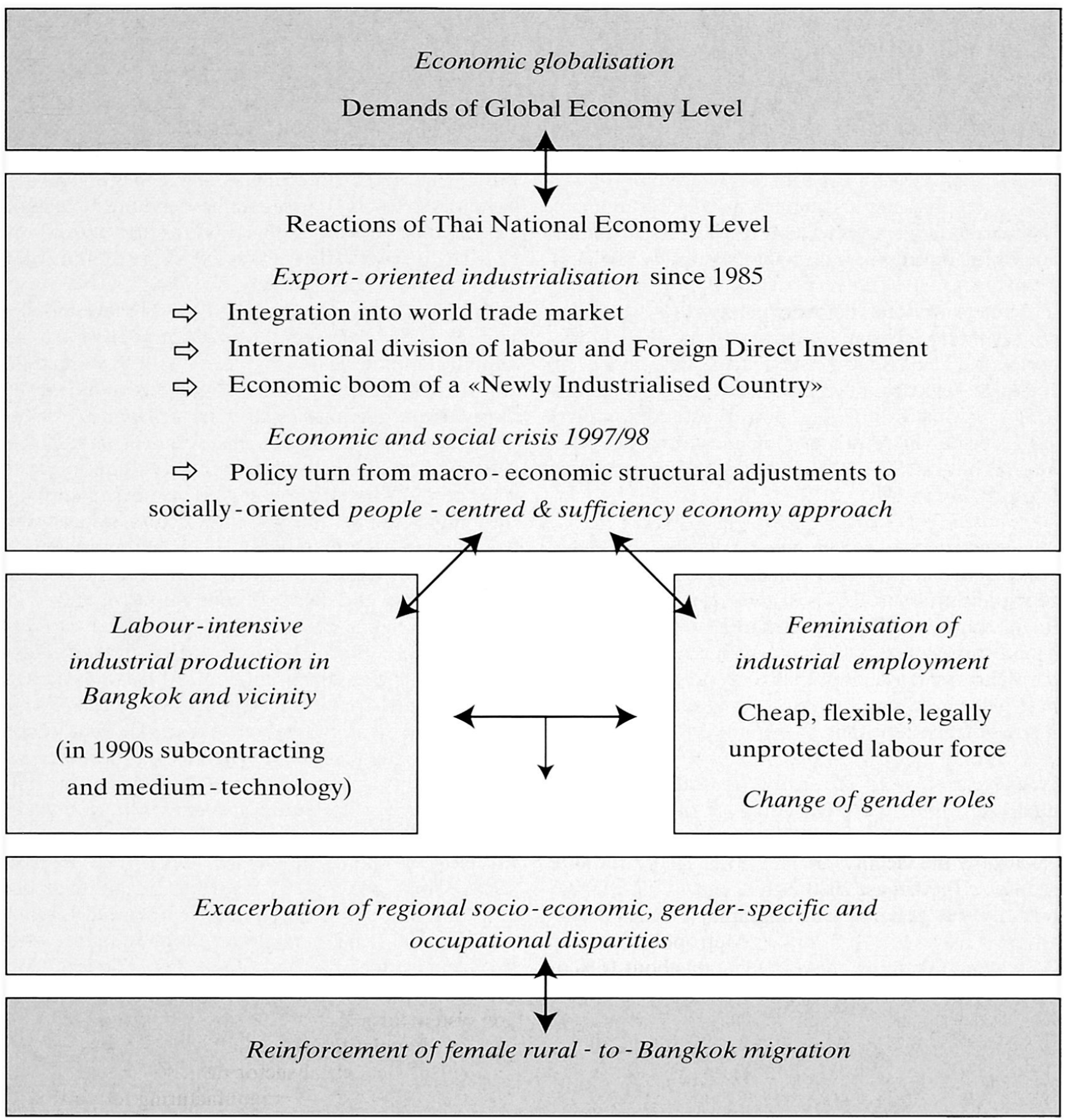

Fig. 2: National dimensions of rural-urban interactions in Thailand Land-Stadt-Beziehungen auf nationaler Ebene in Thailand Relations entre le monde rural et le milieu urbain à l'échelle nationale, en Thaïlande Draft: A. Clausen

4 Individual perspectives on rural-urban interactions

\subsection{Shifts in social relations, life-styles, and identities} The interviews indicate that most Thai female labour migrants in Bangkok and their rural families and communities retain social relationships at least at initial stages of the migration process. Through dynamic exchange networks they communicate material and immaterial goods as well as channel more migration. The major contact points are material remittances, par- 
ticularly money. Gender-specifically, a higher percentage of women remit higher percentages of their salaries, often more than what they keep for themselves (Richter et al. 1995; Chamratrithirong et al. 1995). The women also transfer so-called social remittances, here behaviours, attitudes and practices. They transmit above all ideas of the urban, modern than-samaylifestyle, emphasising consumerism and entertainment. For explanation experts refer to the Thai Buddhist image of people possessing what they deserve: In Buddhism life is mainly the responsibility of the individual. Therefore, merit-making which aims at the collection of positive karma, is an essential part in the daily routine of the Thai. As a consequence - despite sincere Buddhism rejecting all forms of material possessions living conditions, status, and power justify themselves and are widely accepted as a manifestation of earlier actions (Mills 1997, 1999; RichTER \& YODDUMNERNAtтig 1992).

Other remittances include higher education targets, political participation, and sewing, computing, mechanical and business skills. From their rural home-bases, the migrants receive especially emotional support; material assistance is usually smaller than the social remittance streams. Households spend about $25 \%$ of their income to support female migrants while only $17 \%$ on their male counterparts (OSAKI 1999).

Exchange networks are based on children-parents relations, community connections or friendship relations. At the family level, interview partners often explain the existence of exchange links with Buddhist tradition: Migrants, particularly females, show gratitude towards their parents through material remittances:

«Daughters are usually the ones to take care of the parents $[\ldots]$ the sons could go to the monkshood to pay debt of gratitude to their parents. But the girls cannot be a monk» (expert interview 1).

Thus Thai internal migration functions as a household strategy according to the new economics of migration theory. However, the networks often serve the accumulation of material status instead of long-term investments. Also, other approaches propose that the women remit in order to retain their options of returning home in case of need, i.e. to pursue their self-interests. On the whole exchange networks reflect both culturally determined, sex-specific family roles and personal, more utilitarian choices and guarantee that they (the migrants and their families) have a back-up system, either way (expert interview 5; DEJONG, RICHTER \& ISARABHAKDI 1996).

When the women visit their rural homes their appearance (modern clothes, make-up, jewellery etc.) conveys an idea of modernity and autonomy, here the than- samay-lifestyle associated with Bangkok. The rural women feel relatively deprived and follow their more experienced role models in search for the same imagined identity. The globalisation of technology and communication creates similar bridges for the rural people to the imagined worlds of Bangkok. The media flows particularly spread the popular than-samay images concerning the display of commodities and the meaning of progress - a possible explanation for their crucial role in exchange and urban networks (MILLs 1997; UNITED Nations Development Program 1999). As a result, migration chains develop which perpetuate mobility and implicitly make the movement less risky and difficult. Migration chains may eventually rework traditional relations in the new Bangkok environment. Socalled ethnic migrant communities or a kind of a village home transplanted arise which are equally part of urban life and a vivid connection to the rural areas (expert interview 9). They serve as shields against vulnerability and homesickness. Interestingly, factory owners were said to prefer the recruitment of friends and family of their trusted workers over recruiting agencies because it was cheaper and more effective for them.

The migrants' sexual, sectoral and spatial concentrations favour the constitution of ethnically independent informal friendship networks as well as formal trade unions. Yet, only about $2 \%$ of the Thai private labour force is unionised. Whereas status and power justify themselves in traditional Thai society, western thoughts of egalitarianism and criticism are not well accepted. Political passiveness and conflict avoidance are more typical (YoddumnERN-ATTIG 1992; RülAND 1998). Therefore, unions' activities of political selfassertion and empowerment, education and training, assistance in legal, health, and money matters often bear new perspectives and personal experiences which oppose traditional values of the migrants. Besides, the interviews and field observations revealed that

"among the [union's] key leader they also play a very active role in terms of to play as a sister, as a adviser, to the members or to the young generation" (expert interview 12).

In fact, trade unions act as informal substitute families for migrants, hence offering hold, advice, and safety.

The question arises whether these urban workers' networks challenge the existence of rural-urban linkages (and associated ethnic communities) because they represent opposing concepts of identity yet offer the same emotional safety. The Bangkok way of life and inherent urbanised gender identity focuses on mobility, independence, sexuality, consumerism, materialism, self-assertion and sometimes political activity, whereas Thai rural life-styles and identities emphasise thrift, modesty, social harmony, and familial responsibilities (Curran 1998; Richter 1992; United Nations Devel- 
opment Program 1999). How do the women deal with their roles as modern women and traditional daughters and which social sphere do they regard as their home? Do they produce a continuum or a divide between their rural and urban existences? There is no straightforward answer. Generally, the compression of time and space facilitates and pushes the migrant's constant contestations between rural-urban divides and continuums, between the traditional daughter and the modern woman. It therefore influences the migrants' tendency to stabilise, intensify or weaken their ruralurban interactions (REYNOLDS 1998).

When filial obligation levels or outweighs the woman's personal wishes for self-assertion the traditional daughter dominates. Bangkok life is viewed as an unfortunate (economic) necessity. The household registration is kept in the rural home. Urban networks of a traditional daughter are generally less dense for they aim at her practical survival and ultimate return. Contradictory interview statements revealed, however, that a traditional daughter may, despite her disapproving attitudes on the surface, adopt some urban concepts (see social remittances). Therefore traditional daughters construct continuous rural-urban interactions by consciously or subconsciously mixing rural and urban characteristics within their life-styles and maintaining intensive linkages until their own return.

Also, migrants can be traditional daughters and view their sojourn to the strange urban world as an exciting temporary encounter before they settle in the provinces. One expert reported from her own research that most elderly rural people had chosen such an adventure in order to upgrade their personal, familial and community-wide status. The inherent individual choice factor in such adventures and its harmonising effect favour the construction of rural-urban continuums.

Circumstances like marriage, generation differences, (familial) economic problems, and simply time can explain why female migrants embrace modernity (Ogena \& DeJong 1999). These women find their identity, their home, in Bangkok and prefer a thansamay-life together with their urban friends and/or partner over familial commitments. Consequently, they do not envisage or long for return migration (any more) and tend to change their official household registration to the city. As a result of these processes, one expert claimed, migration

«...has already changed the culture of the people. So they have not rural culture any more, they belong to the urban culture. So they fit to the [...] luxurious things in Bangkok» (expert interview 11).

Such women may experience and activate two forms of divide: Firstly, they themselves live through a personal divide which ends in the rejection of their former rural identities. And secondly, they may eventually discard their exchange networks with the rural. Ruralurban interactions become «... more widening» in a self-reinforcing process with

«the whole aspect of Bangkok life [becoming] so different from the rural way of life» (expert interview 3 ).

The pattern of the translocal migrant was most popular with the interview partners and in literature. In face of the increasing concentration of economic choices in Bangkok on the one hand and ever-lasting commitment to the province on the other, a translocal migrant manages an emotional and economic compromise between her traditional and modern role(s). As Table 1 shows, Bangkok is for translocal migrants their place of work, of than-samay lifestyle, and of personal status accumulation whereas the rural origin is their emotional home and place of rest. The latter is related to the parents, the former stands for friendships. Translocal women in fact

«think our home is still home, so but, because of we have to work here and we work already a long time, so this is like second home $[\ldots]$ Their lifestyle is like a cross-culture. They have their old culture and then they adapt to a new culture in a few instants here. But after that when they return they have to change again with their own culture» (expert interview 2).

In fact, the migrants lead bi-localised lives. Almost all migrants follow the translocal pattern at least initially.

A translocal migrant may experience inner conflict because she feels torn between forces of reality (her life in Bangkok) on the one hand and commitment to the rural on the other. In its pragmatic consequence such inner divide leads to an outside continuum: Firstly, the woman's rural and urban existences are functional complements in one overall system of life and thus shape a rural-urban continuum. Secondly, the migrants create a connected space of exchanges. To one expert these processes suggest that

«... maybe the cultural divide is not that great. Could well be [...] diffusion and divide, it could be valid that the people don't feel it» (expert interview 9).

In a reverse perspective the rural-urban gap is seen to be widening because the functional subdivision of the migrants' socio-spatial environments may reinforce regional and gender-specific economic roles (see chapter 3).

\subsection{Thai answers to divide and continuum: Pragmatism and adaptability}

Pragmatism and adaptability facilitate the migrants' lives across space and distinguish their perception of dividing situations from Western beliefs. The interviewed migrants, for example, only stressed typical Western problems discussed at their unions, like workers' exploitation and human rights, because the unions 


\begin{tabular}{|c|c|}
\hline Rural area of origin & Bangkok \\
\hline Nothing to do, no work & Work \\
\hline Love & \\
\hline Warmth & \\
\hline Support by & Support by \\
\hline Family, parents & $\begin{array}{l}\text { Friends } \\
\text { Relatives in Banokok }\end{array}$ \\
\hline & Trade union \\
\hline Backwards & Modern \\
\hline & Shopping \\
\hline & Entertainment \\
\hline & \\
\hline No money & Money \\
\hline \multirow[t]{5}{*}{ Quiet, smooth, peaceful } & Fight for lives \\
\hline & Being serious, concentrated \\
\hline & Responsibility for ourselves \\
\hline & Knowledge \\
\hline & $\begin{array}{l}\text { Trade union activities/ } \\
\text { education }\end{array}$ \\
\hline
\end{tabular}

Tab. 1: Associations made by migrants regarding their lives at their rural origin and in Bangkok, interview information

Assoziationen der Migrantinnen mit ihrem Leben in Bangkok sowie ihrer ländlichen Heimat

Associations faites par les migrantes entre leur vie à Bangkok et dans leur région d'origine

Source: A. Clausen (2000): Interviews with migrants

had channelled these images to them (being financed by western donors). The women's own problem-awareness might be essentially different:

«It is so easy to say that these people are disadvantaged and marginalised and so forth. But you see this is relative. It is how the woman compares herself in this setting and in another setting and which is better. And my theory is women make choices as they move alone. They weigh you know the benefits and cost of each choice» (expert interview 6).

Labour migration can actually be defined as one of the ways in which Thai women make use of their opportunities. It has its advantages and disadvantages - «That is simply the way life is» (expert interview 9). Following the Buddhist idea of karma Thais are generally less anxious and more accepting (KraAs 1997). Therefore, westernised (policy) approaches are meaningful, yet they should consider that typical Thai attitudes, and thus the viewpoint of the people concerned, may be disparate.

With respect to social relations and identities the practicality of the Thais allows them individual freedom in actions. They approach relationships with a high degree of uncomplicatedness and flexibility which in turn enable them to maintain these ties in times of economic hardship and high spatial mobility. Hence, migrants' negotiations of different identities and ruralurban interactions are eased. Similarly, Thais view the growing impact of globalisation on the entire Thai society, particularly in terms of the Westernisation of status values, with pragmatism: They see their Thainess as continually evolving and globalisation as only one historical phase in the Thai tradition of adaptation. Thus, the translocal life-style of migrants can be interpreted as one expression of such pragmatic adaptation to globalisation as well as to the opposing roles of modern women and traditional daughters. YodDUMNERN-ATTIG (1992) even argues that Thailand has not experienced a breakdown of the traditional family unlike many other Asian countries undergoing industrialisation, globalisation and migration processes. Even so, as mentioned before, the economic and social crisis of 1997/98 challenged familial rural-urban safety nets. Returnees could not be accommodated in the provinces and remittances declined in value (although they were usually not suspended). Subsequently, many translocal migrants took on the role of modern women and fought for their rights together in the city. Thus, the crisis introduced new forms of social cohesion for migrants mainly in Bangkok vicinity; rural-urban interactions were no longer important, and familial reliance on them considered too risky. From a different point of view, however, the comparatively calm and non-violent reactions to the crisis in Bangkok were explained to be rooted in the notwithstanding persisting influence of social safety and cohesion, which are traditionally associated with the rural life-style, on the urban people. Finally, one can say, that the crisis both intensified the existing rural-urban divide(s), and encouraged counteractive trends (KraAS 2000; United Nations Development Program 1999).

\section{Conclusion}

In the structural arena of a (macro) economic functional system between the four peripheral regions and Bangkok and its vicinity Thai female labour migrants negotiate and produce identities of modern women and traditional daughters and create both rural-urban divides and continuums. Traditional daughters orientate their way of life towards their rural home and establish vivid rural-urban exchanges, hence a continuum, whereas modern women identify with the Bangkok environment only, eventually rejecting all ruralurban linkages, thereby inducing rural-urban divides. However, most migrants typically find an in-betweenanswer to their in-between situation: They become translocal migrants and define their cultural selves across a geographically fragmented space which they link through social actions. With their traditional traits of flexibility and pragmatism they manage not to feel 
torn, i.e. divided between their two homes nor to be socially disembedded but to belong to two places simultaneously. They ultimately shape socio-economic translocal migration systems, based on family and friendship as the micro and meso-level counterparts to the macro-economic regional functions.

The discourse has shown that the impacts of globalisation are always incorporated in local behaviours. The Thai societal system, the family, and the individual play equally important roles in rural-to-Bangkok migration undertaken to mitigate arising instabilities due to globalisation. Thus, Thai labour migrants' actions across space and time are expressions of their lives being situated in the local and the global, they are expressions of glocalisation.

Summed up, in-between-categories increasingly replace stereotypical categories of the local and the global, the rural and the urban, and the modern and the traditional. Hence, Thai migrants' actions across space and time fit the complex order of a globalising world inbetween networking and disjunctures.

\section{References}

Appadurai, A. (1996): Modernity at large. Cultural dimensions of globalization. - Minneapolis, London: University of Minnesota Press..

BECK, U. (1999): Was ist Globalisierung? - Frankfurt am Main: Suhrkamp.

Chamratrithirong, A. et al. (1995): National Migration Survey of Thailand. - = Institute for Population and Social Research (IPSR), Mahidol University publication No. 188, Bangkok.

Chant, S. (1998): Households, gender and rural-urban migration: reflections on linkages and considerations for policy. - In: Environment and Urbanization 10, 1: 5-21.

Curran, S. (1998): Migration and cultural change: a role for gender and social networks? = The Center for Migration and Development Working Paper Series, No. 6, Princeton: Princeton University.

DeJong, G., Richter, K. \& P. Isarabhakdi (1996): Gender, values, and intentions to move in rural Thailand. - In: International Migration Review 30, 3: 748-770.

Gender and Development Research Institute (GDRI) (1999): Data on the socio-economic situation of Thai women in 1998. - Bangkok.

Gender and Development Research Institute (GDRI) (2000; unpublished at the time of research): Data on the socio-economic situation of Thai women in 1999. Bangkok.

Gosh, J. (1999): Impact of globalization on women: women and economic liberalization in the Asian and Pacific region. $-=$ Economic and Social Commission for Asia and the Pacific Women in Development Discussion Paper Series No. 1, Bangkok.

Granovetrer, M.S. (1973): The strength of weak ties. In: American Journal of Sociology 8, 6: 1360-1380.

GraY, R. (1999): The effects of globalization on labour force and migration in Thailand. $-=$ Economic and Social Commission for Asia and the Pacific Population and Development Working Paper Series No. 8, Bangkok.

GuPTA, A. \& J. Ferguson (1997): Beyond «culture»: space, identity, and the politics of difference. - In: Gupta, A. \& J. Ferguson (eds): Culture, power, place. Explorations in critical anthropology. - Durham N.C., London: Duke university press: 33-51.

Kelly, P. \& K. Olds (1999): Questions in a crisis: the contested meanings of globalisation in the AsiaPacific. - In: OLDS, K. et al. (eds): Globalisation and the Asia-Pacific. Contested territories. - London, New York: Routledge: 1-16.

KraAs, F. (1997): Megastädte: Urbanisierung der Erde und Probleme der Regierbarkeit von Metropolen in Entwicklungsländern. - In: Holtz, U.: Probleme der Entwicklungspolitik - = Cicero Schriftenreihe 2, Bonn: 139-178.

KraAs, F. (2000): Ursachen und Folgen der thailändischen Währungs-, Finanz- und Wirtschaftskrise. In: Sander, I. \& G. Reinecke: Thailand: Aktuelle Wandlungsprozesse in Politik, Wirtschaft, Umwelt und Gesellschaft. - = Mitteilungen des Instituts für Asienkunde 328, Hamburg : 107-141.

MASSEY, D. (1994): Space, place and gender. - Oxford: Oiolity Press.

Mills, M.B. (1997): Working for wages in Bangkok. Reworking gender and family in the countryside. - In: Somswasdi, V. \& S. Theobald: Women, gender relations and development in Thai society. - Women's Studies Center, Faculty of Social Sciences, Chiang Mai University: $137-161$.

Mills, M.B. (1999): Thai women in the global labor force. Consuming desires. Contested selves. - New Brunswick, New Jersey, London: Rutgers University Press.

Ministry OF Labour and Social Welfare (1999): Yearbook of Labour Statistics. - Bangkok.

Moghadam, V.M. (1999): Gender and Globalization: Female Labor and Women's Mobilization. - In: Journal of World-Systems Research 5, 2: 301-314.

National Statistical Office (NSO) (1997): Report of the Migration Survey. - Bangkok.

National Statistical Office (NSO) (2000; unpublished at the time of research): Report of the Labour Force Survey. Whole Kingdom Round 3: August. Bangkok.

Ogena, N.B. et al. (1997): Globalization with equity: policies for growth in Thailand. $-=$ Mahidol University Institute for Population and Social Research Publication No. 214, Bangkok.

Ogena, N.B. \& G. DeJong (1999): Internal migration 
and occupational mobility in Thailand. - In: Asian and Pacific Migration Journal 8, 4: 419-446.

OLwIG, K.F. (1997): Cultural sites: sustaining a home in a deterritorialized world. - In: OLwIG, K.F. \& K. HASTRUP (eds): Siting culture. The shifting anthropological object. - London: Routledge: 17-38.

OSAKI, K. (1999): Economic interactions of migrants and their households of origin: Are women more reliable supporters? - In: Asian and Pacific Migration Journal 8, 4: 447-471.

Parnwell, M. \& J. Rigg (1996): The people of Isan, Thailand: missing out of the economic boom? - In: DWYer, D. \& D. Drakakis-Smith (eds): Ethnicity and development. Geographical perspectives. - Chichester u.a.: Wiley: 215- 248.

RAPPORT, N. (1996): Migrant selves and stereotypes. Personal context in a postmodern world. - In: PILE, S. $\&$ N. THRIFT: Mapping the subject: geographies of cultural transformation. - London, New York: Routledge: 267-282.

REYNOLDS, C.J. (1998): Globalization and cultural nationalism in modern Thailand. - In: KAHN, J.S.: Southeast Asian identities. Culture and the politics of representation in Indonesia, Malaysia, Singapore, and Thailand. - Singapore: Institute of South East Asian Studies: $114-145$.

Richter K. \& B. Yoddumnern-Atrig (1992): Framing a study of Thai women's changing roles and statuses. - In: Yoddumnern-Attig, B. et al.: Changing roles and statuses of women in Thailand: a documentary assessment. - = Mahidol University Institute for Population and Social Research Publication No. 161, Bangkok: 1-7. Richter, K. (1992): Role strain, deprivation and conflict. - In: Yoddumnern-ATtıG, B. et al.: Changing roles and statuses of women in Thailand: a documentary assessment. - = Mahidol University Institute for Population and Social Research Publication No. 161, Bangkok: 98-104.

Richter, K. et al. (1995): Migration and the rural family: Sources of support and strain in a mobile society. - = Mahidol University Institute for Population and Social Research Publication No. 190, Bangkok.

RoberTson, R.: (1998): Glokalisierung: Homogenität und Heterogenität im Raum. - In: BECK, U. (Hrsg.): Perspektiven der Weltgesellschaft. - Frankfurt am Main: Suhrkamp: 192-220.

RoBINSON, V.(1996): Introduction: the geographical contribution to the study of human migration. - In: RoBINson, V:: Geography and Migration. Glos, Vermont. - The international library of studies on migration 2: xi -xvii.

RüLAND, J. (1998): Politische Systeme in Südostasien. Eine Einführung. - = Geschichte und Staat 313, Landsberg am Lech.

SKELDON, R. (1997): Rural-to-urban migration and its implications for poverty alleviation. - In: United Nations Asia-Pacific Population Journal 12, 1: 3-16.

SKELDon, R. (1999): Migration of Women in the Con- text of Globalization in the Asian and Pacific Region. - = Economic and Social Commission for Asia and the Pacific Women in Development Discussion Paper Series No. 2, Bangkok.

StAlKeR, P. (2000): Workers without frontiers. The impact of globlization on international migration. Geneva: International Labour Office, Boulder, Colo.: Lynne Rienner.

Stark, O. (1991): The migration of labor. - Oxford: Blackwell.

TAColi, C. (1998): Beyond the rural-urban divide. Introduction. - In: Environment and Urbanization 10,1:3-4. Thailand Development Research Institute (TDRI) (2000a; unpublished at the time of research): Labour market in Thailand and the Southeast Asian transitional economies: growth, poverty reduction and adjustment to crisis. - Thailand, Bangkok.

Thailand Development Research Institute (TDRI) (2000b): Social impact assessment: synthesis report. Bangkok.

UlLMAN, E.L. (1980): Geography as spatial interaction. - Seattle, London: University of Washington press.

United Nations Development Program (UNDP) (1999): Human Development Report of Thailand 1999. - Bangkok.

United Nations Secretariat New York (1993): Types of female migration. - In: United Nations Department for Economic and Social Information and Policy Analysis: Internal migration of women in developing countries. Proceedings of the United Nations expert meeting on the feminization of internal migration. Aguascalientes, Mexiko, 22.-25.10.1991, New York: 94-115.

Werlen, B. (2000): Die Geographie der Globalisierung. Perspektiven der Sozialgeographie. - In: geographische revue 1:5-20.

World Bank Thailand Office (2000): Thailand social monitor. Thai workers and the crisis. - Bangkok.

YodDumnern-Atrig, B. (1992): Thai family structure and organization: changing roles and duties in historical perspective. - In: YodDUMnern-ATtig, B. et al.: Changing roles and statuses of women in Thailand: a documentary assessment. $-=$ Mahidol University Institute for Population and Social Research Publication No. 161, Bangkok: 8-24.

\section{Summary:«Rural-Urban Divide or Continuum?» On the consequences of female labour migration to Bangkok for rural-urban interactions in an age of globalisation}

On the national level of rural-urban interactions in Thailand economic globalisation produces spatial, sectoral and sexual disparities which trigger female labour migration from the periphery to industrial employment in Bangkok and its vicinity. In geographical terms these dynamics establish an economic system (or continuum) between the periphery and the mega-city. On 
the individual level migrants negotiate shifting identities and social relations. Literally the "traditional daughter» meets the «modern woman». As a result, each migrant produces a distinct pattern of Bangkokperiphery interactions. "Traditional daughters» usually envisage return migration and thus maintain vivid rural-urban relations. «Modern women» may cut off the link with the rural in the long run, influenced by marriage, generation differences, and socio-economic crises, such as that of 1997/1998. Most typically, «translocal migrants» view Bangkok as their place of work and status accumulation yet remain socio-culturally committed to the rural environment. With traditional Thai pragmatism they manage not to feel torn and ultimately shape continuous rural-urban relations. Thus, «in-between» categories increasingly replace stereotypes of «the global» and «the local», «the rural-traditional» and «the urban-modern».

\section{Zusammenfassung: Stadt-Land-Beziehungen im Wandel - Auswirkungen der Arbeitsmigration thailändischer Frauen nach Bangkok unter dem Einfluss der Globalisierung}

Die ökonomische Globalisierung vertieft die wirtschaftliche Schere zwischen Land und Stadt in Thailand und verstärkt die Arbeitsmigration thailändischer Landfrauen in die industrielle Beschäftigung nach Bangkok. Geographisch betrachtet entsteht so letztendlich ein funktionales Austauschsystem zwischen Megacity und der Peripherie. Auf individueller Ebene sieht sich jede Migrantin mit verschiedenen sozialen Welten und Identitäten konfrontiert: Die traditionelle Tochter trifft auf die moderne Stadtfrau. Als Folge dieser Auseinandersetzungen produziert jede Migrantin distinkte BangkokPeripherie-Beziehungen. Traditionelle Töchter planen ihre Rückkehr in die Heimat und erhalten Stadt-LandKontakte aufrecht, während moderne Stadtfrauen sich für ihr städtisches Lebensumfeld entscheiden und ihre Heimatbeziehung aufgeben. Die Mehrzahl der Migrantinnen wählt den translokalen Mittelweg: Bangkok ist der Ort ihrer Arbeit und beruflich-persönlichen Qualifikationen. Dennoch bleiben sie sozio-kulturell mit ihrer Heimat verbunden. Ihr thailändischer Pragmatismus hilft gegen innerliche Zerrissenheit und beim Aufbau stabiler Bangkok-Peripherie-Beziehungen. Zusammenfassend ersetzen Zwischen-Kategorien vermehrt Stereotypen des Globalen und Lokalen sowie des Ländlichtraditionellen und Städtisch-modernen.

\section{Résumé: Rapports villes-campagnes en mutation - Répercussions des migrations de travail de femmes thailandaises vers Bangkok sous l'influence de la mondialisation}

La mondialisation économique accentue la fracture entre le monde rural et le milieu urbain thaïlandais. Elle renforce aussi les migrations de travail vers les industries de Bangkok, affectant les femmes thaïlandaises. Il s'agit là, en fin de compte, sous l'angle géographique, d'un système d'échange fonctionnel entre la mégacité et sa périphérie. A l'échelle individuelle toutefois, chaque migrante négocie des identités et des relations sociales mouvantes: la fille traditionnelle se heurte à la femme moderne de la ville. Par suite de cette confrontation, chaque migrante produit des relations spécifiques entre Bangkok et sa périphérie. Les filles traditionnelles envisagent leur retour dans leur région d'origine et maintiennent les contacts entre le monde rural et le milieu urbain, alors que les citadines modernes se décident pour l'adoption de leur environnement urbain et renoncent à leurs liens avec leur «patrie» d'origine. La plupart des migrantes optent en faveur de la voie médiane translocale, Bangkok devenant le lieu de leur travail et de leurs qualifications tant professionnelles qu'individuelles. Elles demeurent néanmoins liées socio-culturellement à leur région rurale d'origine. Leur pragmatisme thaï est un support contre le déchirement intérieur et en faveur de la construction d'une vie de relations stables entre Bangkok et sa périphérie. En résumé, les observations montrent que les catégories intermédiaires remplacent de façon croissante les stéréotypes du global et du local, ainsi que ceux du traditionnellement rural et de la modernité urbaine.

\section{Didaktische Hinweise}

- What are the consequences in Thailand of the multi-layered interconnectivity between globalisation processes and urban-rural relations?

- Which other group of workers, besides factory workers, is affected by globalisation processes? What is their situation in comparison to the factory workers?

- What were the socio-cultural effects of the economic crisis of $1997 / 98$ ? What was the situation in Thailand in comparison to the other Southeast Asian countries? What typically Thai characteristics are the cause for the different reactions and consequences to be found here?

- From the point of view of the migrants, their families, Thai society in general and the economy, what are the advantages and disadvantages of rural migration to Bangkok?

Dipl.-Geogr. Anne Clausen, Department of Geography, University of Cologne, Albertus-Magnus-Platz, D-50923 Cologne, Germany. e-mail: anne.clausen@uni-koeln.de

\section{Manuskripteingang/received/manuscrit entré le} 16.7.2002

Annahme zum Druck/accepted for publication/accepté pour l'impression: 16.2.2004 